Island Studies Journal, Vol. 9, No 1, 2014, pp. 135-154

\title{
A small separate fatherland of our own: regional history writing and regional identity on islands in the Baltic Sea
}

Janne Holmén

The Institute of Contemporary History, Södertörn University

\& Department of History, Uppsala University

Sweden

janne.holmen@hist.uu.se

\begin{abstract}
Gotland, Åland, Saaremaa, Hiiumaa and Bornholm are five islands in the Baltic Sea which constitute, or have until recently constituted, provinces or counties. Combining perspectives from the fields of island studies and history, this article investigates how regional history writing has contributed to the formation of regional identity on each island since the year 1800. The special geographic situation of the islands - somewhat secluded from the mainland but also connected to important waterways - has provided their inhabitants with shared historical experiences. Due to varying geographic and historical circumstances, the relationship between regional and national identity is however different on each island. While regional history writing has often aimed at integrating the island into the nation state, it has on Alland in the $20^{\text {th }}$ century been used to portray its inhabitants as a separate nation.
\end{abstract}

Keywords: Åland; Bornholm; Gotland; Hiiumaa; island studies; regional identity; Saaremaa; uses of history

C 2014 - Institute of Island Studies, University of Prince Edward Island, Canada.

\section{Introduction}

The most renowned comparative investigation of nationalism in $19^{\text {th }}$ century Europe is Hroch's Social preconditions of national revival in Europe. It investigates the social and geographic origin of the nationalist movements in several European countries, among them Finland and Estonia. One might expect this work to provide insights into the national sentiments on the Finnish archipelago of Åland and the Estonian islands of Hiiumaa and Saaremaa. However, on the maps depicting the territorial distribution of the Finnish and Estonian national movements, all three islands are omitted (Hroch, 1985 pp. 73, 83). Hroch mentions that the Estonian islands were the least nationally active areas in the country, and the omission of Åland is probably due to the same cause.

In 1905, the need for a written history of Åland was discussed in an editorial in the island's then only newspaper, Tidningen Aland (12 August). The writer concluded that Ålanders might be inspired by events in general Finnish history, but not as much as the mainlanders. The fact that Åland was a nation of its own was the island's weakness as well as its strength. Its weakness since it made the Finnish patriotic movements less fruitful than on the mainland; and its strength because, 
it endows us with a small separate fatherland of our own beside the big one, a country that we can more easily fathom with mind and feeling, a country, which is ours and exclusively ours. This patriotism of ours is no parochialism. It is fully justified because of historical as well as geographical circumstances (ibid.).

The idea of an Ålandic history writing presented in 1905 became realized later in the $20^{\text {th }}$ century. However, then it was no longer seen as a complement to Finnish patriotism. In the inter-war period it was instead conducted in order to prove Åland's ancient links to Sweden, while after the Second World War it gradually became more independent and portrayed the Ålanders as a separate people.

The fact that the three islands constitute blind spots on Hroch's maps of national identity suggests that identity formation on islands is connected to special traits, which deserve a distinct and thorough investigation. In combination with the above mentioned example from Åland in 1905, a number of interesting questions are raised. Do islanders in general tend to construct regional island identities as a complement to - or even instead of - patriotic feelings towards the sovereign state to which they belong? If so, which are the historical and geographical circumstances that bring this about? Can these circumstances also explain the frequent shifts of national affiliation which are displayed in Ålandic history writing, and can similar shifts be discerned elsewhere under similar historical and geographical conditions?

This article will show how historical and geographical factors in interplay have contributed to the formation and transformation of collective identities on five large islands in the Baltic Sea: Alland, Gotland, Bornholm, Saaremaa and Hiiumaa. My aim is to investigate how the geographical situation of islands - isolation in combination with potentially far-reaching waterway connections - affects the formation of collective identities, under the influence of political changes and cultural processes. It investigates if and how a regional island identity has been expressed in regional history writing on the large islands in the Baltic Sea during the 19th and 20th centuries, with a particular focus on how it is related to national identity.

I describe the islands investigated here as regions since they constitute - or have until recently constituted - administrative units directly under the level of the state. The source material of the study is regional history writing from these five islands published after the year 1800. Regional history writing is defined as publications which are written by present or former inhabitants of the islands, or which have been published with the help of institutions from the islands. Regarding the content, regional history writing is defined as publications that cover the history of the entire island region, and not those which only cover single municipalities, towns or smaller islands which constitute part of the island region. Publications that treat the islands as part of a larger region have also been excluded. For example, Hiiumaa was until recently often included in works about Läänemaa county, to which the island belonged administratively until the Second World War; but these books cannot be considered part of a process to build a separate Hiiu identity.

The image of the islanders' identity which is captured by this method and selection of sources is neither an ethnological description of feelings at the grassroots level, nor an overview of the general academic history writing of the islands. Neither is it an investigation of mainland perception of islands, as conducted by John Gillis (2004) in Islands of the mind. Rather, we are trying to unravel the islanders' own formulations of who they are, where they come from and what heritage they have in common with fellow inhabitants on their own island, narratives which are cornerstones in the construction of identity. It has to be remembered that history writers do not represent a cross section of any island society, but 
rather an elite stratum, trying to impose its definition of identity upon the island's population. This is no different from how history writing functions on a national level, and studies of the use of history for the construction of national identity is an established research field since the 1980s. This article is a contribution to the less investigated research field of how history has been used to construct identity on a regional level that also happens to be island constituted.

\section{Collective identities: origins and meaning of the concept}

The word 'identity' has a history going back to ancient Greece and Aristotle, but according to the political scientist W.J.M. Mackenzie (1978, p. 19, 30f) it was not fully developed in the sense of collective or political identity before the publication of Lucian Pye's Aspects of Political Development in 1966, although it had occasionally been used in its present meaning by historians and other scholars in the first half of the 20th century. Mackenzie is of the opinion that the concept "collective political identity" evolved in the American academic community from the mid-1950s, stimulated by the awareness of decolonization. Lucian Pye (1966, p. 63) outlined six crises that a society had to overcome before becoming a modern nation state, the first of them being "The Identity Crisis",

The first and most fundamental crisis is that of achieving a common sense of identity. The people in a new state must come to recognize their national territory as being their true homeland, and they must feel as individuals that their own personal identities are in part defined by their identification with their territorially delimited country. In most of the new states, traditional forms of identity ranging from tribe to caste to ethnic and linguistic groups compete with the sense of larger national identity (ibid.).

Thus, the concept of collective identities has its origin in the study of national identity. However, it is not only on a national level that individuals might identify with a particular place and its inhabitants. Although the traditional identities that Pye mentions are not primarily territorial, old and new nation states alike are competing with local and regional identities on many different levels, such as village, town, parish, municipality, county, neighbourhood, or ward. In this study, we use the term "region" for geographic entities directly under the national level.

The concept of local identity was already used by the American social worker Robert Archey Woods in 1898, referring to districts in New York:

The reestablishment of a degree of local self-government in this great district is positively necessary, not only for the political training of citizens, but for securing the local identity and local loyalty out of which the feeling of social responsibility springs. American democracy does not contemplate the formation of vast, sprawling, formless masses of population governed from a single centre (Woods, 1898, p. 307).

Thus, Woods saw a direct link between local identity, democratic participation and social responsibility. Although it did not use the term 'identity', the contemporary local heritage movement in the Nordic countries had similar ideas about the virtue of cultivating the knowledge of and affinity for one's local community. 
Regional identities often function in harmony with national identity; as the examples above illustrates they can even be seen as building blocks for a functioning national democracy. In these cases, local or regional history writing is not trying to tear down the national historical narrative, only to reassert the region's position within it. For example, regional historians in Sweden have often tried to place the cradle of the Swedish kingdom in their own province. The home region is seen as the origin, the core or the most important part of the nation, not as something distinctly different from it. However, regional identities might also become rivals of national identities. A strong regional identity might appear as a more natural community than the nation state, in some extreme cases even leading to demands for independence and the formation of a new nation state - regionalism turned into nationalism and secession.

\section{Islands: sharp borders and strong identities?}

It has been argued that islands have an exceptional ability to instil a sense of local or regional identity among their inhabitants. Geographers, social scientists, anthropologists and political scientists have stated that populations on islands share a feeling of belongingness and affinity that is a consequence of "islandness", the specific isolation and boundedness characteristic of islands. (e.g. White, 1995, p. 4; Olausson, 2007, p. 29; Hay, 2006, p. 22; Royle, 2001, p. 11; Baldacchino, 2004, p. 272f). The term islandness also implies that local identity is not only quantitatively stronger on islands than in mainland communities, but also that it is qualitatively different: it includes the awareness of being an islander, ensconced and secluded with one's fellow islanders at some distance from the rest of the world. During the last decades of the $20^{\text {th }}$ century, "island studies" has emerged as a distinct field of research. Political scientists and geographers wanted to investigate the specific social, economic and political conditions that were linked to the geographic condition of islandness.

Investigations about the connection between geography and politics had however been common already in the first half of the $20^{\text {th }}$ century, when it was labelled geopolitics. Most geopoliticians had little interest in islands, preoccupied as they were with the power struggles between great powers. However, the Swedish political scientist Rudolf Kjellén (1916, p. 54ff) argued that the sea was the best possible border, and that the insular state therefore was the ideal. Notably, he stressed that the role of the border was not to protect the state as a shell. Rather, it had to be a compromise between enclosure and communication, and the sea offered the best combination of those properties. Of course, the location of the island affected the extent to which the surrounding sea provided protection and communication. While Kjellén considered Great Britain's location to be almost perfect, he was of the opinion that New Zealand was too isolated from the viewpoint of efficient communications.

In his great work on the Mediterranean in the time of Philip II, the French historian Fernand Braudel (1976, p. 150) concluded that islands are isolated only as long as they are outside the normal sea routes; when integrated into the trade routes they become actively involved in the dealings of the outside world. As a consequence, islands might be both far ahead and far behind general history, torn between archaism and innovation.

By recognizing the dual nature of islands' boundaries, Kjellén and Braudel touched upon a subject that has become one of the major themes within the field of island studies: the question whether islands are strictly isolated or not. According to Hay (2006, p. 4f), the idea that islands are secluded worlds is not much in favour in contemporary island studies. Instead as being seen as a sharp border, the shoreline is described as a "shifting liminality" or a 
"permeable membrane". Hay summarizes this view with the statement that "connectedness describes the island condition better than isolation". Because of their small hinterlands, islands are forced to trade in order to get access to vital goods; the smaller the islands are, the more dependent they are upon trade.

While the image of islands as delimited by sharp borders lends itself to support the hypothesis that islanders acquire a strong local identity, the idea that islands are highly dependent upon trade also has consequences for the formation of identity. It is a common assumption that collective identity is formed in confrontation and contrast to other groups. An island that is too isolated might not even be aware of its own islandness. Baldacchino (2004, p. 273f) claims that localism might be a way for elites on autonomous islands to configure their relationship to the mainland. He states that "[t]he conception and expression of island identity [...] are part of an ongoing dialectic between the geographic and the political". Baldacchino also underlines that islandness is a relational quality: "an island's administration might be seen to act as a 'mainland' by the inhabitants of outlying islands, enhancing the latter's sense of island identity" (ibid.)

The surrounding sea secludes islands from the rest of the world and provides them with natural boundaries. However, it is equally true that the sea can act as a medium for communication and trade. Clarke and Clarke (2009) argue that isolation and connection should be viewed as complementary, rather than mutually excluding properties of an island. This seemingly paradoxical aspect of islandness is often mentioned, but has so far not been satisfactory empirically investigated.

\section{Identity and history: invented traditions, imagined communities or common heritage?}

In the last decades, historians and sociologists have developed several theories about how collective identities have taken form. The focus has mainly been on national identity, and an important part of the discussion concerns how identity often rests upon a notion of a common history, origin or heritage.

The Invention of Tradition argued how national traditions that were perceived as ancient in fact were often deliberate inventions, not more than a few decades old (Hobsbawm \& Ranger, 1983). In that same year, Anderson claimed that nations were imagined political communities. Modern nations were too large for the citizens to have ever been in direct contact with each other, but they still shared a sense of community. According to Anderson, it was modern print-capitalism that enabled the formation of these imagined communities.

Anders Linde-Laursen (1995, p. 1143), who has studied how the national border and the national differences between Sweden and Denmark have formed, is of the opinion that "[t]he relation between nation building and spatial limits on geographic movement is one of the most central points of Anderson's Imagined communities", but that this aspect of his work is less known than the concept of imagined communities and the emphasis on print capitalism.

The year 1983 also saw the publication of Ernest Gellner's Nations and nationalism, where he argued that nationalism was a consequence of the division of labour within industrial society. New generations were no longer socialized by the local community, but by the national education system. Gellner (1983, p. 34) argued that such a system was constituted by a pyramid, with its top formed by universities training the educators of primary school teachers. This pyramid was the minimum size required for a functioning political unit, and that sub-units of society were no longer capable of social reproduction. 
Gellner's argument offers little prospect for the survival of regional identities in the industrial age, and the islands in this study are not large enough to sustain the whole pyramid. However, we believe that regional history writing might offer an alternative avenue for the social reproduction of units too small to sustain their own teacher education. In fact, several of the islands studied in our research project have at times produced regional school textbooks, where regional history writing is incorporated. Since 1991, Åland has an independent school system, regulated by separate laws and curricula, and can in this respect be compared to a nation state. The teachers are however trained at Swedish or Finnish universities - a reflection of Gellner's (1983, p. 48) claim that a modern state below a certain size has to be parasitic on its neighbours.

Gellner (1983, p. $63 \mathrm{ff})$ believes that, in industrial societies "[t]here is very little in the way of any effective, binding organization at any level between the individual and the total community", which leaves little room for strong regional identities. However, he acknowledges that there might be obstacles to the entropy which eradicates all differences within the nation, mentioning genetic and cultural factors like race and religion. Although Gellner does not mention geographic factors, it is not unlikely that they too might have a similar function.

Not all researchers emphasize the recent, constructed and imagined dimension of national identity. Anthony D. Smith (1986; 1991; 2000, p. 62ff) is of the opinion that nation building requires the pre-existence of a core "ethnie", which share a common denomination, a myth of origin, a common history, a distinct common culture, a territory and a sense of solidarity. It should be noted that Smith is not a perennialist in the sense that he considers nations as necessary and constant, but he believes they are formed around certain old and recurring myths and symbols.

To explain the existence of nations which is obviously not constructed around an old core ethnie, like the state of Tanzania, Smith (1986, p.11) has argued that these "depleted" ethnies are forced to create political religions or single-party states in order to build a national identity.

Local and regional identity has often been seen as less imagined and more genuine than national identity. After all, in a much smaller local community, people have a greater possibility of meeting each other in person. It might be argued that this aspect of the local community is enforced if it is located on an island; since the sea restricts travel to a certain extent, the islanders' daily encounters with other people are more restricted to members of the local community than what would be the case if the border had not been there. However, the Swedish historian Peter Aronsson (2004, p. 133) is of the opinion that this view of how local identity is formed is somewhat romanticized. Narratives might be mediated in a different way in the local community than on a national level, oral traditions being more important in smaller communities; but identity is still constructed through narratives. In addition to that, local narratives are also dispersed in publications, just like national history writing. 
Regional history writing and regional identity on Baltic islands

\section{The development of regional history writing on Baltic Islands: 1804-2013}

\section{The islands}

In spite of their relative proximity to each other, the islands in the Baltic Sea have developed under different geographical and historical circumstances.

The Swedish island of Gotland is the largest of all Baltic islands, with a population of some 57,000 on a land area of $3,000 \mathrm{~km}^{2}$. Administratively, Gotland has, together with a few smaller islands, been one of Sweden's 21 counties (län). Gotlands län consisted of only one municipality (kommun), which was also called Gotland. On 1 January 2011, Gotland's county and municipality merged into Region Gotland. The island is also one of Sweden's 25 historical provinces (landskap). Today, Gotlanders generally consider themselves Swedes, but the medieval language of Gotland is considered by linguists as a language separate from Swedish. Before the 14th century, Gotland was largely autonomous, with a loose bond to the Swedish kingdom. However, in 1361, Gotland was attached to the Danish realm, and a period of economic stagnation began. In 1645, Gotland was passed over to Sweden.

Aland is an autonomous province (landskap) in Finland, the main island situated $70 \mathrm{~km}$ from the Finnish mainland and $36 \mathrm{~km}$ from the Swedish mainland. Mainland Åland is connected to mainland Finland by an archipelago with the highest density of islands found anywhere in the world. (Depraetre and Dahl, 2007, p. 71) The Åland islands are constituted by nearly 7,000 islands each larger than 0.25 ha, with 60 of them populated. Counting smaller islands, Åland has around 27,000, with a total land area of 1,552 $\mathrm{km}^{2}$. Alland had 28,500 inhabitants as at 31 December 2012, and it is the only Baltic island region studied here with a growing population. The official language on Alland is Swedish, the mother tongue of $90 \%$ of Åland's and 5\% of Finland's population. Åland and Finland were integrated parts of Sweden until 1809, when they came under Russian sovereignty. In the autumn of 1917, a movement was formed on Åland which wanted the island to secede from Russia to join Sweden. However, Finland which gained its own independence from Russia in December that year, wanted to keep Åland within its borders, which caused a conflict with Sweden over the sovereignty of the islands. To appease the Ålanders, Finland offered the island autonomy. The League of Nations granted Finland sovereignty over Åland in 1921, on condition that the language and culture of the inhabitants were safeguarded. The island was granted autonomy in line with the Finnish suggestion.

Saaremaa is an Estonian county (maakond). In addition to main Saaremaa and adjacent small islands, it consists of the sizeable island Muhu and the smaller, more distant Ruhnu in the Bay of Riga. Saaremaa county has a land surface area of $2,922 \mathrm{~km}^{2}$ and a population of 34,527 , down from around 40,000 in the early 1990s. Today, 98\% of residents on Saaremaa and Hiiumaa speak Estonian; but German was commonly spoken until World War II. It was the language of the landed aristocracy and of the merchants in its capital, Arensburg (modern day Kuressaare). Ruhnu had a Swedish speaking population that deserted the island for Sweden during World War II. Saaremaa was invaded by German crusaders in 1227, and the island was (like Hiiumaa) divided between the Brothers of the Sword (from 1237 the Livonian Order) and the bishopric of Oesel-Wiek, which also comprised present day Läänemaa on the mainland. In 1559, Saaremaa was united to Denmark, which handed the island over to Sweden in 1645. In 1710, Russian troops gained control over the island, and it remained part of the Russian empire until the end of the First World War, when Estonia gained independence. Kuressaare/Arensburg is situated on the southern coast of Saaremaa and has enjoyed good 
connections to Riga, in modern day Latvia, which was the centre of Livonia. The distance from the southern tip of Sõrve peninsula to Latvia is less than $30 \mathrm{~km}$. Saaremaa constitutes $6.5 \%$ of Estonia's land area and is home to $2.6 \%$ of its population. That makes it the relatively most sizeable island in the investigation compared to the mainland, although Gotland is larger in absolute terms. Prior to the Second World War, 60,000 persons, 5\% of the country's total, lived on Saaremaa.

With a surface area of $1,023 \mathrm{~km}^{2}$, Hiiumaa is the smallest of the island regions investigated in this paper. It is also largely made up of wetlands and other infertile areas, which has meant that historically it has had a relatively small population. Hiiumaa was probably populated from Saaremaa and Sweden in the 13th century. The presence of Swedish peasants was greater than on Saaremaa, and they remained a sizeable community until the end of the 18th century. Hiiumaa was also under Swedish rule but for longer than Saaremaa, from 1563 to 1710. Just like Saaremaa, the island suffered heavy population losses during the Second World War. The population is still decreasing and in 2012 it had dipped to 9,984 persons. Kärdla on Hiiumaa didn't gain city rights until 1938, and not until 1946 when Hiiumaa became a separate county did Kärdla replace Haapsalu on the mainland as the administrative centre of the island. By that time, Estonia had become a Soviet republic, and the Estonian islands remained affected by travel restrictions until Estonia regained independence in 1992.

Bornholm is part of Denmark and has, with a few interruptions, been so since the late $10^{\text {th }}$ century. The island has however been highly contested. In the Middle Ages, it was the scene of a power struggle between the Danish king and the archbishops of Lund in Scania, the part of Denmark to which Bornholm had the closest ties. From 1525 until 1575, the island was leased to Lübeck, and in 1658 it was ceded to Sweden together with Scania and other provinces in eastern Denmark. An uprising in December of the same year brought the island back under the control of the Danish king. As a reward for their part in the uprising, the Bornholmians were granted several privileges, including exemptions from certain taxes and military service outside their island. Scania and the rest of eastern Denmark were however permanently lost to Sweden, which meant that Bornholm now became situated far $(135 \mathrm{~km})$ from Denmark, while Sweden lay within a distance of $35 \mathrm{~km}$. From 1940 to 1945, the island was under German occupation, like the rest of Denmark. In contrast to the rest of the country, Bornholm also experienced a year of Soviet occupation, from May 1945 until April 1946. Unlike the other islands in this study, Bornholm has several urban centres which were established already in the Middle Ages. The total population of the island today is 41,000, and it is steadily shrinking. Bornholm is the only area in Denmark labelled Regionskommune, a title it received on 1 January 2003 when the island's five municipalities were amalgamated with Bornholms amt (county) after a referendum. When Denmark abandoned the amts system in favour of regions on 1 January 2007, Bornholm became part of Region Hovedstaden.

\section{Early $19^{\text {th }}$ century regional history writing}

The regional history writing carried out on the islands in the Baltic Sea has undergone several phases, each of them related to different patterns of identification. In the first half of the $19^{\text {th }}$ century, nationalism was still in its infancy in northern Europe, and regional history writing was not yet permeated by national ideology. The regional history writers active during this period - such as the student Peder Nikolai Skougaard $(1804,1834)$ on Bornholm and the governor of Saaremaa Baron Peter Wilhelm von Buxhöwden (1838) - were instead motivated by a will to defend the privileges of the groups with which they identified, and to indirectly 
criticize autocratic rulers. Skougaard defended the privileges which Bornholm had acquired as a consequence of the 1658 uprising, and particularly defended Bornholm's poorer peasants. His direct criticism of Danish kings and the mismanagement of the island rendered him a sentence of fourteen days on bread and water and lifelong censorship (Jacobsen, 1975 p. 12ff). Skougaard considered Bornholmian to be a separate language more similar to Swedish than Danish, and compared the situation of the Bornholmian peasants to that of Norway and other peripheral lands in the Danish realm, rather than to the serfs in Denmark proper.

Von Buxhöwden instead defended the privileges of the Baltic German nobility on Saaremaa, and his criticism of the ruler was more shrewd and covert than Skougaard's. For example, he made a historical comparison of patriotism on Saaremaa during the Swedish and Russian periods in Saaremaa's history, and concluded that the Swedes had lost support since they tried to reduce the landholdings of the nobility and interfered in their rule of the local community. The comparison tacitly implied that Tsar Nikolai I might suffer a similar loss of popularity if he strayed from the established Russian policy of non-interference in regional affairs.

Ideologically, writers like Skougaard from Bornholm and Johan Wilhelm Ludwig von Luce (1827) on Saaremaa combined the traditions of the enlightenment and romanticism, promoting practical knowledge and improvements while describing the history and popular culture of the peasant population. Von Luce described the late $12^{\text {th }}$ and early $13^{\text {th }}$ centuries as a golden age for the Saaremaa islanders, and based on his practice as a physician on Saaremaa, he claimed that contemporary Estonians were less degenerate than Germans.

No regional history writing had yet taken place on the two smallest island regions, which at the time still lacked towns: Åland and Hiiumaa. Gotland had seen regional history writing in the Middle Ages and in the $16^{\text {th }}$ and $17^{\text {th }}$ centuries, but none took place in the first half of the $19^{\text {th }}$ century.

\section{Mid-1 $9^{\text {th }}$ century to the First World War}

The period from the mid- $19^{\text {th }}$ century up until the First World War was characterized by an intensified process of nation building in Sweden, Denmark and Finland. Persons belonging to the regional elite on Gotland, Bornholm and Åland - which now had a town since Mariehamn was founded in 1861 - started associations, museums and periodicals. They wrote books (e.g. Bomansson, 1852, 1858; Snöbohm, 1871; Jørgensen, 1900-1901,) and articles on their island's past, with the purpose of integrating their regions into national history. The uprisings on Aland against Russian troops in 1809 and on Bornholm against the Swedes in 1658 were interpreted in nationalist terms.

Bornholmian history writers during this period were Danish nationalists, and the most prominent of them were Johan Andreas Jørgensen and Marius Kristian Zahrtmann, who continued to be productive in the interwar years and published a two-volume overview of the island's history in 1934-1935. They were both positive to the integration of Bornholm as a more normal part of Denmark which took place during their lifetime. They did not regret the loss of privileges, like exemptions from taxation and military service outside of Bornholm, which the island experienced in the $19^{\text {th }}$ century. For example, Zahrtmann $(1935$, p. 238f) considered it positive that the islanders now did military service in Denmark proper, as it contributed to the creation of a more Danish generation of Bornholmians. 
Ålander Karl August Bomansson was one of the pioneers of Finnish history writing, archaeology and the first director of the national archives. In his writings about the uprising in 1809 (Bomansson, 1852) and Åland's antiquity (Bomansson, 1858), he claimed that Ålanders were neither Finns nor Swedes but primarily Ålanders. He saw influences from both east and west in Åland's historical development, and claimed - based on place names - that the island's population of Swedophone farmers had been preceded by Fennophone hunters. Åland was not drawn into the battle between the Svecoman and Fennoman versions of Finnish nationalism until the early 1890s, and sided decisively with the Swedish-minded Svecomanism - although nationalism probably never developed deep roots outside the small regional elite which to a large extent had its origin on the Finnish mainland.

In the second half of the century Gotlandic history writers, foremost amongst them the schoolteachers Per Arvid Säve, Carl Johan Bergman and Alfred Theodor Snöbohm, established a narrative of their island's past which has remained relatively unchanged until today. They emphasized the Middle Ages when Gotland, they claimed, was a centre for Baltic trade and governed as a peasant republic (Edquist, 2014).

On Saaremaa, regional history writing was still carried out in a feudal setting and was entirely restricted to the Baltic-German elite. No history writing permeated by Estonian nationalism - or even written in the Estonian language - took place on the island during this period, which corresponds well with Miroslav Hroch's view of the Estonian islands as white spots on the map of nationalism. The writings of the most productive history writer on the island, the pastor Martin Körber, instead displayed what might be described as an emergent Livonian patriotism: a nationalism of a nation which never came to be. As a consequence of this, he held a negative view of periods when Saaremaa was more independent of the mainland. For example, Körber (1885, p. 146) regarded it a "regrettable spectacle" that the island part of the bishopric of Oesel-Wiek was ruled autonomously. He believed this recurring misfortune was caused by the fact that the bishopric, which comprised parts of Saaremaa as well as mainland areas, was divided by the sea.

Körber $(1885$, pp. 3f, 22, 29) held the pre-Christian Saaremaa islanders in high regard. They raided the coasts of the Baltic and were the last Estonians to be subjugated by German crusaders. Körber believed that, although the Saaremaa warriors were inferior to the Germans, they were superior to mainland Estonians and Latvians, and on a par with Swedes and Danes. At the dismemberment of the Russian empire after the First World War, the Livonian governorate was divided between the new republics of Estonia and Latvia, which were formed on the basis of linguistic borders.

\section{The inter-war period}

In the inter-war period, the process of national integration continued on Gotland and Bornholm, and it also took off on Saaremaa where the island was written into Estonian history as a volume (Luha, Blumfeldt \& Tammekann, 1934) in the work Eesti, which covered the entire country. In contrast to the earlier Baltic German history writing from Saaremaa, the peculiarities of the island and its links to Livonia were no longer emphasized. Instead, the island was written into general Estonian history. For example, while Körber (1885, p. 54) claimed that the Great Uprising on Saaremaa in 1343-1345 was caused by the love of freedom characteristic of islanders and mountain dwellers, all later history writers have seen it as part of an even larger uprising, encompassing Harju province on the mainland as well. Meanwhile, on Åland, history took a different turn since most islanders in the years 1917-1918 shifted from 
Finnish to Swedish nationalism. This happened during a struggle for reunification with Sweden, which was fuelled by security concerns caused by the Russian revolutions, and eventually led to autonomy for Åland within Finland in 1922.

On Åland and Saaremaa, the regional museums which had been in the hands of associations dominated by the elite were taken over by the new regional governments, which mainly represented the peasant class, after the First World War. The provincial government on Åland also appointed an archaeologist, Matts Dreijer, with the deliberate aim of protecting the island's autonomy by strengthening the Ålanders' identity (Dreijer, 1984 p. 131). In the interwar period, Dreijer's writings were emphasizing Åland's ancient historical links to Sweden, following the example of the Swedish historians which had championed Sweden's cause in the struggle for Åland (e.g. Dreijer 1937, 1943). The idea that ancient Åland had been the home of a Fennophone population was now discarded: Ålanders were now protecting their island against what they described as "Fennification", and consequently tried to keep Finns out of their history too.

Meanwhile, during the inter-war period, Saaremaa's rural landscape and peasant culture became Estonian national icons (Sooväli, 2004). A similar development had begun on Gotland already at the turn of the $20^{\text {th }}$ century (Edquist, 2014).

\section{Changes brought about by the Second World War}

The Second World War brought changes to most of the Baltic islands, with the exception of Gotland, where history writing continued down the same path, centred on the Middle Ages and with the island's political affinity to Sweden never in doubt. The Soviet annexation of Estonia meant that regional history writing on Saaremaa split into a Soviet branch carried out on the island, often in cooperation with the commission for local history at the Estonian Soviet republic's academy of science, and a national Estonian branch which continued the inter-war tradition in exile from Canada or Sweden. The two branches similarly had their main focus upon the fate of the peasant population. However, the Soviet regional history writers wrote more negatively about the Danish and Swedish periods in Saaremaa's history, blaming problems during the Russian period on the feudal Baltic German nobility, not the Russian rulers which they claimed brought peace and order to the island. The medieval uprisings were still considered important, but now described as part of the "Estonian peasantry's ceaseless struggle against the [...] German feudal yoke" (Allik, 1959 p. 35ff).

Communist history writers, as the former NKVD official Vassili Riis (1960) put great emphasis on the uprising on Saaremaa against the young Estonian government in 1919, which they saw as proof of the islanders sympathy for the peasants and workers in mainland Estonia and the Soviet Union. This event had by nationally minded writers been treated as a tragic mistake caused by misinformation brought on by the island's isolation. In the early 1970s, the first Hiiumaa regional history writing was produced in exile in Sweden (Vrager, 1971).

In Åland's early 1950s, archaeologist Matts Dreijer brought about a new orientation in regional history writing, emphasizing Åland's independence and importance rather than its links to Sweden. This was in line with the new political orientation on Åland, where the hopes of reunification with Sweden had been replaced with an urge to achieve an improved law of autonomy, which was accomplished in 1951. Dreijer's vision of a great autonomous Ålandic 12 th century as a predecessor to contemporary political autonomy became fully developed in the first volume of Det åländska folkets historia ("The history of the Ålandic people", 1979). There, he claimed that the Viking Age trading place Birka had been located on Åland, not on 
Björkö in the Swedish lake Mälaren which is the consensus among academic scholars. He was also of the opinon that $\AA$ land had, in the $12^{\text {th }}$ century, been a base for Danish crusades to Finland. Although Dreijer now de-emphasized Åland's historical political ties to Sweden, the island's linguistic and cultural Swedishness - the official foundation of Åland's autonomy within Finland - was still vehemently defended.

In the Second World War, Bornholm was bombed and occupied by Soviet forces. The Danish government's inability to assist the Bornholmians during these events led to disappointment on the island. It is often mentioned that, while Bornholm was bombed, the rest of Denmark was celebrating the end of the War and the Bornholmian resistance movement could not even get the Danish ministers to answer their phones. Regional history writing from the period after the war is less positive towards Bornholm's integration into Denmark, and the criticism against Copenhagen has increased since the turn of the millennium (e.g. Bøggild, 2004 p. 16f; Rasmussen, 2008, p. 177). The grievances included the unpopular decision to decommission the military forces on Bornholm, the unsatisfactory state of ferry services, and the fact that Bornholm (through the regional reform of January 2007) had become part of the Hovedstaden region, which is governed from Sjælland. These contemporary complaints are often linked to what is perceived as a Danish historical tendency to forget Bornholm and not consider it as part of Denmark proper.

Late $20^{\text {th }}$ - early $21^{\text {st }}$ centuries

In the late $20^{\text {th }}$ and early $21^{\text {st }}$ centuries, the islands saw a wave of critical use of regional history writing. A strand of more academic research emerged on Åland (Nordman, 1984; Högman, 1984) which questioned or problematized many of the myths of regional history writing and culture. Academic history writing also started to question how democratic and important Gotland really was in the Middle Ages, although this reorientation was only partially reflected in more popular works (Edquist, 2014). On Åland, some of the criticism was clearly connected to the moral tendency in contemporary - particularly Swedish - history writing, criticising racist and nationalistic tendencies in the island's early $20^{\text {th }}$ century society (Mattsson-Eklund, 2000 p. 341).

Like Bomansson in the mid-1800s, Allanders are again describing themselves as neither Finns nor Swedes. However, when Bomansson's idea that Ålandic place names indicated a previous Finnish settlement of the island was developed in a book by a Swedish scholar (Hellberg, 1980) the idea was vehemently opposed by Ålanders. Åland's past and present monolingual Swedishness had been the unchallenged cornerstone of Ålandic identity since the First World War; but during the peace movement of the 1980's Åland's demilitarization appeared as an alternative - or rather a complement, since mono-lingualism was never really shaken. Already in 1979 the publisher Johannes Salminen (p. 181) claimed that that instinctive pacifism has become a second nature of Ålanders, and the idea became popular especially among politicans on the political left.

On Saaremaa, the collapse of the Soviet Union was followed by a period of intense criticism of Soviet crimes, which was however succeeded in the early $21^{\text {st }}$ century by a more nuanced and varied history writing. Crimes committed by other parties in the Second World War were by then also acknowledged, and some (e.g. Saar \& Tombak, 2007) even admitted that the Soviet period had left a lasting impression in certain areas of Estonian society. 


\section{Regional history writing: a threat to national identity?}

In the cases of Gotland, Hiiumaa and Saaremaa, regional history writing does not emphasize tensions between the island and the mainland (that is, Sweden and Estonia respectively). In fact, on these islands it is difficult, if not impossible, to draw a line between regional and national history writing. Gotland's history, and especially its Middle Ages, is seen as an important part of Swedish history. Similarly, Saaremaa is considered to have played an important role in what is described as a national Estonian struggle against invaders in the early $13^{\text {th }}$ century. The cultural and historical landscapes of Gotland and Saaremaa (Sooväli, 2004) have also become national icons, perceived as relicts of how Sweden and Estonia looked in the past. A substantial corpus of scholarship on Saaremaa's and Gotland's history have been produced in cooperation between writers and institutions from the islands and the mainland, and in 2008 large parts of the Swedish National Heritage Board were relocated to Gotland. On these three islands, the formation of a regional identity has not been connected to any political separatism.

Åland and Bornholm have developed differently. On these two islands, one can (with a few exceptions) make a clear distinction between regional and national history writing. In the early 1900s, both Åland and Bornholm seemed to be heading towards becoming wellintegrated parts of the Finnish and Danish national edifices. The few Ålanders who wrote history emphasized Åland's important role in Finland's history; some of them in fact belonged to the pioneers of Finnish national history writing.

However, the development was interrupted by the Russian revolution and the Ålanders' quest for security by attempting to unite their island with Sweden. As a counter-strategy, the Finnish authorities invented Ålandic political regionalism by offering the islanders autonomy, which eventually removed the Ålandic dreams of reunification with Sweden from the political agenda.

The Danish government has acted very differently towards Bornholm. The Denmark of today is the remnant of what was once a vast conglomerate state of loosely bound provinces stretching from Greenland to Estonia. As long as Denmark was a dominating power in the Baltic Sea, these provinces were bound together by water. However, from the late 1500s onwards, Denmark's might was waning, and the Baltic waterways now came to separate the Danish provinces from each other, rather than to unite them. One by one, the leaves peeled off as province after province was lost.

The Danish nation state which was formed from the mid-1800s was, as a reaction to the old loose conglomerate state, highly centralized. In a country which has lost region after region since the 1500 s, regionalism is not encouraged. Equally, as Denmark is divided by waterways, the idea of the sea as a natural boundary is not favoured - especially since natural boundaries has been a common Swedish legitimization of the conquest of Scania from Denmark in the 1600s. Since the mid-1800s, Bornholm has lost all of its special privileges, and it is since 2007 been administered as part of Region Hovedstaden, which also encompasses parts of Sjælland including Copenhagen.

In recent decades, the reactions on Bornholm towards the long-term effects caused by removal of political power from the regional level have become increasingly negative. Bornholmian history writers express that, as a forgotten periphery in the east, they have no friends in Copenhagen; while Denmark's western periphery, Jutland, rakes in political support and benefits. Thus, the autonomous Ålandic regional authorities have successfully used the 
international agreements regarding Åland's status in their power struggles with the parliament in Helsinki; but the Bornholmians, who lack autonomy, have to compete with other Danish areas for the favours of the central authorities in Copenhagen. To make their voices heard in this competition, Bornholmians still refer to their strong Danish patriotism, claiming to be the most Danish of all Danes.

\section{Mechanisms behind the formation of strong regional identities on Baltic islands}

Åland, Gotland, Bornholm and Saaremaa display strong regional identities, illustrated by a rich production of regional history writing, and in recent decades regional identity has been strengthened also on Hiiumaa. The fact that most of the islands have been administrative units for long periods in history, and that the borders of these units correspond with old provincial borders, is critical for the development of regional identity. It cannot however be denied that the blueprint for these administrative borders is drawn by geography, which has surrounded the islands with water. The islands' insularity has meant that, although they have been impacted by the same historical processes as the mainland, they have experienced the effects in a slightly different way. In the $19^{\text {th }}$ and early $20^{\text {th }}$ centuries, industrialization transformed life in the entire Baltic region, but while it brought with it factories and railroads on the mainland, on many of the islands it took the form of peasant shipping, globalizing rather than nationalizing the identity of the islanders in the process. Times of war and unrest affected the islands differently than the mainland; depending upon the belligerent parties' ability to make use of the sea in their warfare, the islands could be hit hard or spared from hostilities. These differences meant that crucial events in national history have been remembered differently on the islands than on the mainland, a phenomenon which is most accentuated on Bornholm and Åland. Using the terminology of Ernest Gellner, islandness can thus be described as an "obstacle to social entropy", a barrier which prevents all parts of the nation from becoming identical under the homogenizing pressure of industrial society.

However, the key factor in differentiating between the islands and their respective mainland is the islands' strategic locations, which have repeatedly rendered each of them an exceptional status. It has been argued that the placement of the border between Sweden and Denmark through the Oresund strait - and maybe the very existence of these as two separate rather than one - is a consequence of the reluctance of great powers to leave any single state in control of that important waterway (Linde-Laursen, 1995). In a similar manner, Åland's demilitarized, neutral and autonomous status is a result of great power politics aimed at avoiding any state's unhindered use of the island for military purposes. The Ålanders have been able to take advantage of this situation in order to expand their autonomy. In the regional government's struggle to strengthen autonomy, regional identity has been intentionally heightened, in part with the aid of history writing. Strong regional identity can thus not be seen as a cause behind autonomy, but is instead the last link in a chain of events: the point of departure was the island's geographic position, which in a certain political setting became of strategic importance, which in turn led to an exceptional legal status and eventually autonomy. Autonomy was acquired as the unintended result of the attempt to join Sweden by the Aland movement, which was also in part fuelled by tensions caused by Åland's geographic insularity. Ålandic history writing and identity building can thus be seen as an attempt to make best use of the situation into which geography and history have thrust it. 
In the case of Bornholm, development has headed in the opposite direction. The regional reform of 1 January 2007 integrated Bornholm with Region Hovedstaden; and, although Bornholms regionskommune has some privileges compared to an ordinary Danish municipality, the reform did remove regional influence from important areas like healthcare. However, regardless of how the administrative borders of Denmark's regions are drawn, Bornholm's geographic location as a peripheral island cannot be taken away, and the identityforming forces which it implies are very much at work today, not least in the form of vivid regional history writing. In the words of Fernand Braudel (1976, p. 164), a "mere" geographic expression is far from insignificant, being "a representation of a historical entity within which events had similar repercussions and effects". It is not the geographic borders per se but the shared historical experience that they impose on the persons living within them which constitute the basis of a common identity. It might be argued that the unpopular reshaping of regional borders constitutes yet another shared experience around which this identity can take form.

The construction of regional identity on islands Baltic Sea is difficult to explain solely by Anthony D. Smith's idea that nationalism is based upon a primordial "ethnie" with a myth of origin, a common history, a distinct common culture, a territory and a sense of solidarity. On the contrary, the sources indicate that even in an island setting, the idea that the inhabitants shared a common territory arose quite late, with local divisions overriding the regional identity well into the $19^{\text {th }}$ century (Holmén \& Edquist, 2014).

The only example we have found of an island where regional identity has developed into micro-nationalism is Aland in the second half of the $20^{\text {th }}$ century. However, that only happened after attempts had been made at embracing first Finnish and then Swedish nationalism. Åland fits badly into the standard model of an ethnie. Compared to Gotland, Bornholm and Saaremaa, Åland is - if we use Anthony D. Smith's terminology - quite "depleted" in terms of myths of origin and a documented common history. The attempts in the 1950s-1980s to invent a history worthy of Åland's autonomous status - by expropriating the past of richer ethnies like Iceland - were met with ridicule from the surrounding world and have now been largely abandoned on the island. The idea of Matts Dreijer (1979) that Åland was the Iceland of the Norse sagas is one of only a few examples of an outright invented tradition (in the sense of Hobsbawm and Ranger) that we have found on the Baltic islands. This illustrates that adaptions and constructions upon firmer historical ground constitute a more common and durable form of identity formation.

In contrast to the multi-ethnic countries without historical precedence which Smith forwards as examples of depleted ethnies, Åland's difficulties to root its autonomy in culture and history is a consequence of the fact that, for at least 600 years, was a well-integrated, centrally located province in the Swedish kingdom which then also encompassed present day Finland. As a result, the island's history and culture is to a large degree shared with the Finnish and Swedish mainland. As in a multi-ethnic depleted ethnie, history and culture are not alone capable of defining what separates Åland from the surrounding world.

In accordance with what Smith expects of a depleted ethnie, Ålandic politics was conducted virtually without opposition and party politics until the 1970s, resembling a single party state. Since then, a party system has been introduced, but simultaneously the veneration of Åland's autonomy and demilitarization has increased, amounting to what Smith describes as a political religion, another avenue by which depleted ethnies might strengthen national identity. 


\section{The isolation-connectedness dialectic of islands in the Baltic Sea}

In 2009, Clarke and Clarke described the fact that islands are isolated and connected at the same time as a case of complementarity. By describing what the combination of seclusion and connection has meant for the formation of collective identities on the Baltic islands, I hope to bring the general understanding of this complementarity forward.

Maritime communications have historically been potentially faster and more efficient than land routes, but they have offered substantially higher risks and been more sensitive to weather and other disturbances. The waterways have been carrying dramatic novelties and exceptional events from distant lands - fleets of invaders, waves of refugees, stranded ships or even stranded fleets - to the shores of the islands. They have also enabled the islanders to take part in Baltic, European and even global trade networks. However, the sea has until recently been unable to function as a safe and reliable medium of uninterrupted everyday communications with the mainland. Although the Baltic islands are situated quite close to the mainland, difficult weather conditions have periodically isolated them, especially in early winter or in springtime when the fragile ice could neither be crossed by foot nor by boat. In several instances, slow communications made the islanders hail different monarchs than the mainlanders, as when, in the spring of 1658, Bornholmians learned they had become subjects of the Swedish king after a month's delay (Rasmussen, 2000, p. 31). In the $19^{\text {th }}$ century, mainland communities become interconnected through the expansion of railroads and regular train services, which has been seen as one important factor behind the rise of nation states and national identities. The islands of the Baltic Sea had to wait much longer for any equally reliable means of everyday communications.

It can be argued that the sea's possibility and yet limitations and irregularities as a means of communication has thus contributed to making the islands somewhat less connected to their neighbouring regions than is the case with mainland regions. At the same time through potentially fast and efficient long distance communications - they have been better connected to distant areas. This has of course had consequences for how well the islands have become integrated into their respective states. On Åland, peasant shippers were crossing the Atlantic half a century before daily, reliable steam boat connections to the mainland were established - or all children had access to folk schools propagating national ideology for that matter. To various extents, Saaremaa, Hiiumaa and Bornholm also took part in this international shipping boom. The fact that, in these cases, globalization preceded national integration might have contributed in making national identity weaker.

\section{A model for identity formation on islands}

Our studies have brought us far from the simple geographic deterministic model that islands, being neatly delimited by natural borders and often relatively small in size, automatically impose a common sense of identity on their inhabitants. However, the idea of islandness cannot be relegated to a mere metaphor, implying that the physical geography of islands is completely irrelevant to the formation of collective identities. Geography does influence regional identity, but through a series of complex historical processes.

Recurrently through history, the islands' geographic location renders them strategic importance and gives them good access to international trade networks; but it also complicates and delays their communications with the mainland states to which they belong. 
Their strategic locations have made the islands subject to fortifications, housing of troops and occupations. This has contributed to the outbreak of regional uprisings or protests which, aided by the islands' relative isolation from the mainland, have sometimes been successful. The islands' strategic locations have also rendered them exceptional statuses. Because of fortifications, Saaremaa and Hiiumaa were subject to travel restrictions during the Soviet period. The uprising in 1658 gave Bornholmians a number of privileges, and the Åland movement in combination with international interest in the strategically important Åland Islands resulted in autonomy in 1921. This kind of exceptional status is maybe the most important factor behind the formation of a strong political identity, manifested in the Ålandic regional identity's transformation in the direction of a national identity in the late $20^{\text {th }}$ century. The islands' relative isolation from the mainland has made it practical to maintain the islands as administrative units, which in the long term has been of importance for the formation of a regional identity. The isolation also contributed to a relatively slow start for the national movement on most of the islands. The difficulty for the national movement to gain hegemony on the islands might also be linked to their good access to international trade networks, which in the second half of the $19^{\text {th }}$ century meant that Åland, Saaremaa, Hiiumaa and Bornholm were deeply involved in the international shipping boom, which connected them to an international network - and especially to Great Britain - rather than to their closer national surroundings.

All five islands studied in this project have experienced periods when they have benefited greatly from their locations close to international trade routes, either through trade, piracy or privateering. On all of the islands, these "Golden Ages" form an important part of regional history writing and regional identity, but on Gotland - where regional history writing is centred on the island's medieval history - this theme is completely dominant.

Although the Baltic islands share many traits, their individual characteristics regarding location, size and political belonging have influenced the construction of regional identity, making every case special. However, these unique identities have all been formed through different combinations of the geographic and historical factors outlined above.

This model of identity formation on islands is based on studies of islands in the Baltic Sea, and these are not necessarily applicable to other islands, regardless of size, location and political circumstances. One does hope, however, that the conclusions reached in this research project might help clarify some of the mechanisms by which island people might form strong regional identities. Historians and other scholars interested in collective identities might thus hopefully rediscover geography as a crucial parameter in identity formation. Although the mechanisms of identity formation outlined here might be most easily studied on islands, they are probably active also in other circumstances when geography and history have interplayed in creating deviations between national and regional historical narratives.

\section{Acknowledgements}

This article summarizes the result of the research project Islands of Identity which was conducted at Södertörn University College, Sweden, 2009-2012. A book emerging from the project will appear in 2014. Special acknowledgments to Samuel Edquist, who has written the chapter about Gotland in the forthcoming book, and to Erik Axelsson, who has functioned as project leader and did an initial survey of sources from Bornholm. Kenneth Gustavsson and Dan Nordman have given valuable comments on Alandic history writing. Katrin Aar at the Archival Library in Kuressaare was of great help in finding sources from Saaremaa. Olavi Pesti 
and Marika Mägi have commented about Saaremaa. The director of Hiiumaa museum, Helgi Põllo, has been of great help in many ways, and Vello Kaskor has also given valuable input about Hiiumaa. From Bornholm, I thank Ann Vibeke Knudsen, former director of Bornholm's museum, the archaeologist Finn Ole Sonne Nielsen and Karin Larsen at the Centre for Regional and Tourism Research. Nils Erik Villstrand, professor at Åbo Akademi in Turku, contributed with insights into the general state of regional history writing in Finland. Professor Torkel Jansson in Uppsala has given valuable feedback on the findings of our research project. Texts related to the projects have received valuable comments from the seminars at the Institute of Contemporary History, Södertörn University and at the Department of History, Uppsala University, Sweden. The usual disclaimers apply.

\section{References}

Allik, A. (1959). 'Ajalooline ülevaade' [Historical overview]. In E. Tooms (Ed.) Saaremaa: Kogumik materjale [Saaremaa: Collected material]. Kingissepa: Kommunismi Ehitaja.

Anderson, B. (1983/2006). Imagined communities: Reflections on the origin and spread of nationalism. London: Verso.

Aronsson, P. (2004). Historiebruk: Att använda det förflutna [Uses of history: To use the past.]. Lund, Sweden: Studentlitteratur.

Baldacchino, G. (2004). The coming of age of island studies. Tijdschrift voor Economische en Sociale Geografie, 95(3), pp. 272-283.

Bomansson, K. A. (1852). Skildringen affolkrörelsen på Aland, 1808: En scen ur Suomis sista strid. Med en öfversigt af Aland $i$ allmänhet. [Depiction of the popular movement on Åland, 1808: A scene from Suomi's last battle. With an overview of Åland in general.] Stockholm.

Bomansson, K.A. (1858). Om Alands fornminnen. [On Åland's ancient monuments.] Helsingfors: Frenckell.

Braudel, F. (1976). The Mediterranean and the Mediterranean World in the age of Philip II. Vol. 1. New York: Harper.

Buxhöwden, P. W. von (1838). Beiträge zur Geschichte der Provinz Oesel. [Contribution to the history of the province Saaremaa.] Riga \& Leipzig: Götschel.

Bøggild, H. (2004). Gyldendals bog om Bornholm. [Gyldendal's book about Bornholm.] Copenhagen: Gyldendals.

Clark, E. \& Clark, T.L. (2009). Isolating connections; connecting isolations. Geografiska Annaler, 91B(4), pp. 311-323.

Depraetere, C., \& Dahl, A.L. (2007). Locations and classifications. In G. Baldacchino (Ed.) $A$ world of islands: An island studies reader (pp. 57-106). Charlottetown, Canada and Luqa, Malta: Institute of Island Studies and Agenda Academic.

Dreijer, M. (1937). Alands forntid och forntida minnesmärken. [Åland's antiquity and ancient monuments.] Mariehamn: Ålands museum.

Dreijer, M. (1943). Aland och ålänningarna. [Åland and the Ålanders.] Helsinki: Söderströms.

Dreijer, M. (1979). Det åländska folkets historia. I:1 Från stenåldern till Gustav Vasa. [The history of the Ålandic people. I: From the Stone Age to Gustav Vasa.] Mariehamn: Ålands Kulturstiftelse.

Dreijer, M. (1984). Genom livets snårskog. [Through the underbrush of life.] Söderströms. 
Edquist, S. (2014, Forthcoming). In the shadow of the middle ages? Tendencies in Gotlandic history writing, 1850-2010. In J. Holmén \& S. Edquist (Eds.) Islands of identity. Huddinge, Sweden: Södertörn University.

Gillis, J. R. (2004). Islands of the mind: How the human imagination created the Atlantic world. New York: Palgrave Macmillan.

Gellner, E. (1983). Nations and nationalism. Oxford: Blackwell.

Hay, P. (2006). A phenomenology of islands. Island Studies Journal, 1(1), pp. 19-42.

Hobsbawn, E. J. \& Ranger, T. (Eds.) (1983). The invention of tradition. Cambridge, UK: Cambridge University Press.

Högman, G. (1986). Alänningarna och ålandsfrågan. [The Ålanders and the Åland question.] In S. Jungar \& N.-E.Villstrand (Eds.), Väster om skiftet: Uppsatser ur Ålands historia. (pp. 117-137). Åbo/Turku: Åbo Akademi, Historiska institutionen.

Jacobsen, F. (1975). Efterskrift til Beskrivelse over Bornholm [Postscript to A Description of Bornholm.] in P.N. Skovgaard: Beskrivelse over Bornholm: Genudgivet med en efterskrift af Finn Jacobsen (pp.1-22). Copenhagen: Rosenkilde \& Bagger.

Jørgensen, J. A. (1900). Bornholms historie: I. Fra Oldtiden til 1660. Rønne: Sørensen.

Jørgensen, J. A. (1901). Bornholms historie: II. Fra 1660 til nutiden. Rønne: Sørensen.

Kjellén, R. (1916). Staten som lifsform: Politiska handböcker 3. [The state as life form: Political handbooks 3.] Stockholm: Geber.

Körber, M. (1885). Bausteine zu einer Geschichte Oesels: Fünf Jahrhunderte, von der heidnichen Vorzeit bis zum Frieden von Nystädt. [Building blocks to a history of Saaremaa: five centuries, from the heathen prehistory until the peace of Nystad.] Arensburg: Typographie des Arensburger Wochenblattes.

Luce, J. W. L. von (1827). Wahrheit und Muthmassung: Beytrag zur ältesten Geschichte der Insel Oesel. [Truth and conjecture. Contribution to the oldest history of the island Saaremaa.] Pernau: Marquardt.

Luha, A., Blumfeldt, E. \& Tammekann, A. (Eds.) (1934). Saaremaa: Maateaduslik, majanduslik ja ajalooline kirjeldus. [Saaremaa: Geographic, economic and historical description.] Tartu, Estonia: Eesti Kirjanduse Seltsi kirjastus.

Mackenzie, W. J. M. (1978). Political identity. Manchester: Manchester University Press.

Mattsson-Eklund, B. (2000). Alla tiders Aland: Från istid till EU-inträde. [Åland of all ages: From Ice Age to EU-membership.] Mariehamn: Ålands landskapsstyrelse.

Nordman, D. (1986). Historiker kämpar om Aland: om de svenska och finländska historikernas argumentering $i$ Alandsfrågan 1917-21. [Historians fight over Åland: the arguments of Swedish and Finnish historians in the Åland question 1917-21.] In S. Jungar \& N.-E. Villstrand (eds) Väster om skiftet: Uppsatser ur Alands historia (pp. 139-158). Åbo/ Turku: Åbo Akademi, Historiska institutionen.

Olausson, P. M. (2007). Autonomy and islands: A global study of the factors that determine island autonomy. Åbo /Turku: Åbo Akademi University Press.

Pye, L. (1966). Aspects of political development: An analytic study. Boston MA: Little Brown.

Tidningen Aland. (1905). Editorial. August 12.

Rasmussen, E. G. (2000). Skuddet: En bog om Villum Clausen og de dramatiske hoendelser under den bornholmske opstand i 1658. Nexø. Bornholm: Editio.

Rasmussen, E. G. (2008). Bornholm og Skåne: Triumf og tragedie i skcebneårene 1658-1659. [Bornholm and Skåne: Triumph and tragedy in the fateful years 1658-1659.] Rønne, Bornholm: TV2 Bornholm. 
Royle, S. A. (2001). A geography of islands: Small island insularity. London: Routledge.

Saar, I. \& Tombak, M. (2007). Saaremaa teise Nõukogude okupatsiooni ajal 1944-1991. [Saaremaa during the second Soviet occupation.] In K. Jänes-Kapp, E. Randma \& M. Soosaar (eds), Saaremaa 2: Ajalugu, majandus, kultuur. [Saaremaa 2: History, economy, culture.] (pp. 345-388). Tallinn, Estonia: Koolibri.

Salminen, J. (1979). Ålandskungen [The Åland king.]. Stockhom: Rabén \& Sjögren.

Skougaard, P. N. (1804). Beskrivelse over Bornholm. 1. del. [Description of Bornholm. 1st. part.] Copenhagen: Seidelin.

Skovgaard, P. N. (1834). Bornholms saga. Aalborg: Lundt.

Smith, A. D. (1986). The ethnic origins of nations. Oxford: Basil Blackwell.

Smith, A. D. (1991). National identity. Reno NV: University of Nevada Press.

Smith, A. D. (2000). The Nation in history: Historiographical debates about ethnicity and nationalism. Hannover NH: University Press of New England.

Snöbohm, A. T. (1871). Gotlands land och folk: Hufvuddragen till en teckning af Gotland och dess öden från äldre till nuvarande tider. [Gotland's land and people: Outline to a sketch of Gotland and its fate from older to present times.] Örebro. Retrieved from http://runeberg.org/gotlands

Sooväli, H. (2004). Saaremaa waltz: Landscape imagery of Saaremaa island in the 20th century. Tartu, Estonia: Tartu University Press.

White, G. M. (1995). Identity through history: Living stories in a Solomon Islands society. Cambridge, UK: Cambridge University Press.

Vrager, E. (1971). Hiiumaa ja hiidlased: Ülevaade saarest ja rahvast. [Hiiumaa and the Hiiumaa islanders: A survey of the island and the people.] Toronto, Canada: Estoprint.

Woods, R. A. (1898). The city wilderness: A settlement study. Boston MA: Houghton Mifflin.

Zahrtmann, M. K. (1934). Borringholmerens historiebog: Første og anden bog. [The Bornholmian's history book: First and second book]. Rønne, Bornholm: Colberg.

Zahrtmann, M. K. (1935). Borringholmerens historiebog: Tredje og fjerde bog [The Bornholmian's history book: Third and fourth book.] Rønne, Bornholm: Colberg. 